\title{
Defining hotspots of characteristic species for multiple taxonomic groups in the Netherlands
}

\author{
M. A. Schouten - A. Barendregt • P. A. Verweij • V. J. Kalkman • \\ R. M. J. C. Kleukers • H. J. R. Lenders • H. N. Siebel
}

Received: 22 July 2009/Accepted: 27 April 2010/Published online: 19 May 2010

(C) The Author(s) 2010. This article is published with open access at Springerlink.com

\begin{abstract}
Biogeographical zonation based on single taxa poses major limitations on planning for nature conservation. This paper identifies biogeographical patterns of multiple taxa in the Netherlands, where no endemics are present at species level, on the basis of characteristic species. We used occurrence data on five species groups in order to identify spatially coherent, ecologically important regions. TWINSPAN was used to cluster grid squares according to similarity in species composition for each taxonomic group. Species that are characteristic of each of the clusters were identified using a preference index, and corresponding clusters among the taxonomic groups were identified with Kappa statistics. Regions containing characteristic species for several taxonomic groups were defined as 'hotspots'. Stepwise discriminant analysis was then used to characterize these hotspots according to differences in environmental conditions. The analysis yielded five regions that are clearly distinct in terms of species composition for individual taxonomic groups. Each region is characterized by a set of unique species that occur in the zonation of at least two of the taxonomic groups. Stepwise discriminant analysis revealed significant environmental differences among these regions. The concept of hotspots as operationalized in this study can make nature conservation planning more efficient. In combination, the hotspots
\end{abstract}

\footnotetext{
M. A. Schouten $(\bowtie) \cdot$ A. Barendregt

Department of Environmental Sciences, Copernicus Institute for Sustainable Development and Innovation, Utrecht University, PO Box 80115, 3508 TC Utrecht, The Netherlands e-mail: mariekeschouten@yahoo.com
}

\section{P. A. Verweij}

Department of Science, Technology and Society, Copernicus Institute for Sustainable Development and Innovation, Utrecht University, PO Box 80115, 3508 TC Utrecht, The Netherlands

\section{J. Kalkman · R. M. J. C. Kleukers}

European Invertebrate Survey-The Netherlands, PO Box 9517, 2300 RA Leiden, The Netherlands

\section{H. J. R. Lenders}

RAVON Foundation/ Department of Environmental Science, Institute of Water and Wetland Research, Radboud University, PO Box 9010, 6500 GL Nijmegen, The Netherlands

H. N. Siebel

Natuurmonumenten, PO Box 9911, 1243 ZR ‘s-Graveland, The Netherlands 
defined here comprise the majority of the species occurring in the Netherlands for the studied groups. Therefore, this regionalization should be taken into account when prioritizing nature conservation efforts.

Keywords Biodiversity - Biodiversity conservation - Conservation biogeography · Characteristic species $\cdot$ Hotspots of characteristic species $\cdot$ Multiple taxa ·

The Netherlands

\section{Introduction}

There is a deep-rooted tradition of studying spatial variation in species composition and delineating distinct ecological areas in terms of differences in species composition. At present, an understanding of the spatial variation in biotic composition and its underlying mechanisms is pivotal to conservation biology (Margules and Pressey 2000). In recent decades, species richness has declined rapidly (Thomas et al. 2004; Millennium Ecosystem Assessment 2005), urging effective conservation and restoration strategies. Ensuing research has yielded numerous strategies for nature conservation. Efforts to prioritize areas for nature conservation worldwide have included circumscribing 'hotspots'; areas with high species diversity or high levels of endemic, rare, or threatened species (Myers et al. 2000; Margules et al. 2002; Fox and Beckley 2005; Tchouto et al. 2006). However, concentrations of overall species diversity and of endangered and endemic species do not necessarily coincide (Prendergast et al. 1993; Orme et al. 2005). A refined method to select areas with high conservation value is to estimate an area's complementarity: the contextdependent, marginal gain in biodiversity that its preservation would provide. Reserve selection methods based on the complementarity principle and the use of advanced computer algorithms are popular (Rodrigues and Gaston 2002; Williams et al. 2006) but, according to Faith et al. (2003), nowhere have the sets of areas thus selected been implemented in regional conservation planning.

In the absence of basic, fine-scaled data on the distribution of most species, both approaches depend on surrogate information. As distribution patterns do not necessarily coincide for different taxonomic groups, it is debatable whether indicator, umbrella, or keystone taxa could serve as surrogates for total biodiversity (Williams and Gaston 1994; Andelman and Fagan 2000; Ricketts et al. 2002; Kati et al. 2004; Wiens et al. 2008). It is also debatable whether the focus should be on mammals, birds, and vascular plants, the dominant trend in conservation research and policy, instead of on overall biodiversity, healthy ecosystems, or the Earth's genetic library (Jepson and Canney 2001). A different approach is to use specific environmental conditions (Pienkowski et al. 1996; Dûfrene and Legendre 1997) such as climate and soil type to represent biodiversity; possibly combined with species distributions (Carey et al. 1995). This approach generates eco-regions that would reflect species distributions and thereby be useful for protecting biodiversity. It is focused on charting an area's characteristic species composition and environmental variation, as biodiversity cannot be captured in terms of species richness alone.

Setting conservation priorities gets even more complicated in a densely populated and industrialized country such as the Netherlands. Here, endemic species are absent and species numbers do not indicate regional priorities, as the patterns of species groups coincide only to a limited extent (Schouten et al. 2009). Given the growing tension in spatial planning between intensive land use and space for nature, the most pressing issue for Dutch conservationists is to determine where the main regions of interest for 
biodiversity are located. Fortunately, the Netherlands is one of the most closely monitored countries in the world. General biodiversity data are available for many taxonomic groups at a detailed level. Thus, there is no need to fill gaps in the data by means of extrapolation or predictive modeling, for example. This study therefore analyzes the patterns of biodiversity directly, without recourse to extrapolation, surrogate species or complementarity approaches.

Patterns in species distribution of well-studied groups such as birds and vascular plants have already been documented for the Netherlands (Witte and van der Meijden 2000; Kwak and van den Berg 2004). However, distribution patterns of different taxonomic groups display varying levels of congruence (Prendergast et al. 1993; Reid 1998; Pawar et al. 2007). This would justify the use of a multi-taxon approach to more accurately represent the country's ecological diversity (Carey et al. 1995; Maes and Bonte 2007; Diffendorfer et al. 2007). Therefore, this paper concentrates on five less-studied taxonomic groups to enable the identification of areas of biogeographical interest for these groups. Apart from alteration of their habitat, these groups are hardly subject to human activities (i.e., planting, hunting) that might change the distribution of populations, and they display a broad range of life strategies. Among the vertebrates, our analysis includes reptiles and amphibians; among the plant species, it includes the mosses. Among the invertebrates, it spans three groups: the aquatic carnivorous dragonflies; the terrestrial phytophagous grasshoppers; and the group of the hoverflies with larvae exhibiting various life strategies (terrestrial vs. aquatic; carnivorous or phytophagous; or saprophytic). A sufficiently large and good-quality dataset on their nationwide distribution was available at a suitable resolution.

\section{Methods}

\section{Research area}

The Netherlands is a small country $\left(41,500 \mathrm{~km}^{2}\right)$ in northwestern Europe. About 2,000 years ago, the sandy inland parts of this region were covered by extensive forests. The western part was largely marshland, swamps, and bogs, separated from the sea by a strip of coastal dunes; the rivers crossing this lowland created a large delta (Zonneveld 1985). More recently, high population density, industrialization, and contemporary landuse practices have radically altered the natural landscape and changed the environmental conditions (i.e., due to nitrogen deposition).

\section{Species occurrence data}

We divided the Netherlands into grid squares of $5 \times 5 \mathrm{~km}$, the resolution at which the bulk of the data was available and the geographical coverage suitable. Only those grid squares with more than half of the terrestrial area lying within the country's borders were taken into account $(N=1,393)$. Species lists for all grid squares were derived from several national databases. Data on hoverflies (Syrphidae), grasshoppers and crickets (Orthoptera), and dragonflies (Odonata) came from the database of the European Invertebrate Survey (EISNL). Herpetofauna (Amphibia and Reptilia) data were obtained from the RAVON Foundation (Reptile, Amphibian and Fish Conservation Netherlands). And data on moss species (Bryophyta) were extracted from the database of the Dutch Bryological and Lichenological Society (BLWG). These sources comprise a diverse assortment of museum records, data 
Table 1 Number of species, number of records, approximate number of collectors, time span over which data were collected, and origin of data for the five taxonomic groups in the Netherlands

\begin{tabular}{|c|c|c|c|c|c|}
\hline & Hoverflies & Herpetofauna & $\begin{array}{l}\text { Grasshoppers } \\
\text { and crickets }\end{array}$ & Dragonflies & Mosses \\
\hline No. of species & 327 & 24 & 45 & 71 & 507 \\
\hline No. of records & 372,118 & 233,206 & 70,000 & 220,000 & 875,000 \\
\hline No. of collectors & 450 & 1000 & NA & 200 & 300 \\
\hline Time span & 1819-2003 & 1820-2002 & 1900-2002 & $1823-2003$ & $1800-2003$ \\
\hline Origin & $\mathrm{C}, \mathrm{F}, \mathrm{L}$ & $\mathrm{F}, \mathrm{M}$ & $\mathrm{C}, \mathrm{F}, \mathrm{L}$ & $\mathrm{C}, \mathrm{F}, \mathrm{L}, \mathrm{M}$ & $\mathrm{C}, \mathrm{F}, \mathrm{L}, \mathrm{M}$ \\
\hline
\end{tabular}

$C$ museum collections, $F$ observations in the field, $L$ literature, $M$ monitoring schemes, $N A$ no data available

from monitoring and literature, species lists of inventories, and ad hoc species occurrence records collected by many volunteers and professionals over a long period of time (Table 1). We only used data on species for which the taxonomic identification is straightforward (i.e., no species complexes were used). To obtain the best fill in the grid squares and to get some idea of the distribution patterns regardless of how the environment has changed over the past 100 years, we chose to use all available records. We did so even though less records are available from the period before 1950 than that from recent years. For species names we followed the nomenclature in Mertens and Wermuth (1960), Beuk (2002), Nederlandse Vereniging voor Libellenstudie (2002), Kleukers et al. (1997), and Siebel and During (2006).

\section{Environmental data}

To explore environmental variation across the regions, we compiled a set of 33 possible discriminating variables (Appendix 1, Table 5). We extracted data on the distribution of different habitat types in the Netherlands from the LGN4 land cover map (Alterra 2001), which is based on information from aerial and satellite imagery. The 39 land cover categories on this map were lumped into 13 habitat types (Appendix 1, Table 5). For each $5 \times 5 \mathrm{~km}$ grid square we calculated the area occupied by the different habitat types. In addition we calculated the Shannon index expressing the land cover heterogeneity in each grid square:

$$
H^{\prime}=-\Sigma p_{i} \ln p_{i}
$$

where $p_{i}(>0)$ is the proportion of area of the $i$-th habitat type in a grid square. Climate data were obtained from the Royal Netherlands Meteorological Institute (KNMI 2002). Relative humidity in spring, duration of sunshine, amount of radiation, temperature and precipitation surplus are given as the mean annual values measured over the period 1971-2000. Elevation was derived from the Dutch national digital elevation model (2002, Rijkswaterstaat). Soil types were abstracted from the Dutch soil type map (Steur and Heijink 1992). Average groundwater level in spring was derived from the map of groundwater classes (Hinsbergen et al. 2001). For data on nitrogen deposition (1995-1997 means) we used the results of the STONE model (Overbeek et al. 2002). Data on pH (1991-1997 means), available nitrogen (1991-1997 means), and salinity (1970-1997 means) were all obtained from Bio et al. (1999). A map depicting the age of the Dutch landscape, based on the last major shift in land cover, was constructed using literature and topographical maps dating from ca. 1850 to 2002 (Cormont et al. 2004). 
Data analysis

We followed a five-step procedure to define the hotspots of characteristic species. First, TWINSPAN was used to cluster grid squares according to similarity in species composition for each individual taxonomic group. Due to large differences in the number of species in the taxonomic groups (Table 1), we analyzed the groups separately instead of combining them from the start. Then we identified characteristic species for each cluster. Subsequently we identified corresponding clusters among the different taxonomic groups and selected regions containing characteristic species for at least two of the taxonomic groups. These regions were then defined as hotspots of characteristic species. Finally, we assessed the environmental differences between these regions.

\section{Identifying regions for individual taxonomic groups}

Species composition of each $5 \times 5 \mathrm{~km}$ grid square was analyzed for each taxonomic group individually, using two-way indicator species analysis (TWINSPAN), a hierarchical divisive numerical classification technique (Hill 1979). We used the adjusted TWINSPAN version as described in Oksanen and Minchin (1997). Highly common species (distributed across the entire country and in $>40 \%$ of the squares) were omitted from the analysis to prevent the formation of separate clusters with a low sampling intensity, as unevenness in sampling intensity is a common problem in the kind of databases used in studies such as this (e.g. Guralnick and Van Cleve 2005). A Geographical Information System (ArcView 3.3) was used to project the resulting TWINSPAN clusters onto a map of the Netherlands. The level of detail of the TWINSPAN analysis, and thus the resulting number of clusters, was guided by the aim of this study: the clusters needed to be spatially coherent and ecologically important.

\section{Identification of characteristic species}

To identify which species were characteristic of each cluster, we calculated a preference index for each species in each cluster. The index was calculated in accordance with Carey et al. (1995):

$$
P=[(o-e) * \operatorname{abs}(o-e)] / e
$$

where $o$ is the observed frequency of a species in a given cluster and $e$ is its expected frequency, the frequency with which it occurs in all grid squares. $P$ is independent of the size of a cluster, allowing comparison of the degree of preference of a certain species among unequally sized clusters. A species was considered characteristic of a cluster if (a) $P$ for that cluster is at least two times as high as for the other clusters and (b) if the species has a frequency of at least $5 \%$ in that cluster.

\section{Similarity between the selected regions}

Based on the preference index scores we identified clusters of grid squares that had characteristic species for each taxonomic group separately. We then selected the regions that geographically coincided for at least two of the taxonomic groups. The degree of similarity among the regions defined for the individual taxonomic groups was compared 
using Kappa statistics (Monserud and Leemans 1992). In general, $<0.2$ represents poor agreement, 0.2-0.4 fair, 0.4-0.6 moderate, 0.6-0.8 good, and 0.8-1 very good (Landis and Koch 1977; Monserud and Leemans 1992).

\section{Defining hotspots of characteristic species}

To generate hotspots of characteristic species, the regions with characteristic species of individual taxonomic groups were first stacked. Then the number of taxonomic groups for which a grid square was designated to the specified region was posted on a map.

\section{Environmental distinction of the hotspots of characteristic species}

We used stepwise discriminant analysis (SDA) to characterize the hotspots of characteristic species in terms of environmental differences. Discriminant analysis tests variables as discriminators of the differences between pre-defined groups. Using a stepwise selection procedure, only the most significant of the 33 possible discriminating variables (listed in Appendix 1, Table 5) were used. The analysis was performed using SPSS 12.0.1 for Windows (SPSS Inc., Chicago, USA). Wilks' lambda significance and the percentage of correct assignments were used to validate the results.

\section{Results}

Regions and their characteristic species

TWINSPAN analysis provided a classification of the Netherlands for the individual taxonomic groups. Only part of the clusters resulting from TWINSPAN appeared to be based on the presence of characteristic species (Fig. 1a-e). Table 2 presents the regions for each taxonomic group that do have characteristic species. We have included the characteristic species found in each region up to a maximum of 10 species.

Similarity between the selected regions

Overall, there was a fair degree of spatial similarity among regions with characteristic species defined for the individual taxonomic groups (Table 3). The coastal dune regions of the individual taxa showed the highest congruence (with one exception, namely that it was not recognized for the dragonflies). There was also reasonable similarity among the regions located in the southern province of Limburg for the different taxonomic groups (Table 3e). All groups, with the exception of the dragonflies, define the Limburg region very well. The grasshoppers and crickets do, however, exhibit a somewhat aberrant pattern. Their occurrence in the Limburg region (O3, Fig. 1b) is not strictly confined to the southern part of Limburg as is the case in the other groups; scattered grid squares with a similar species composition are also found in the rest of the country. There was less congruence in the patterns of the five taxonomic groups found in the southeastern part of the country. The patterns exhibited by the hoverflies deviated most from those of other groups. In the southeastern region, this deviation is explained by the small number of grid squares assigned to that region (S1, Fig. 1d). 

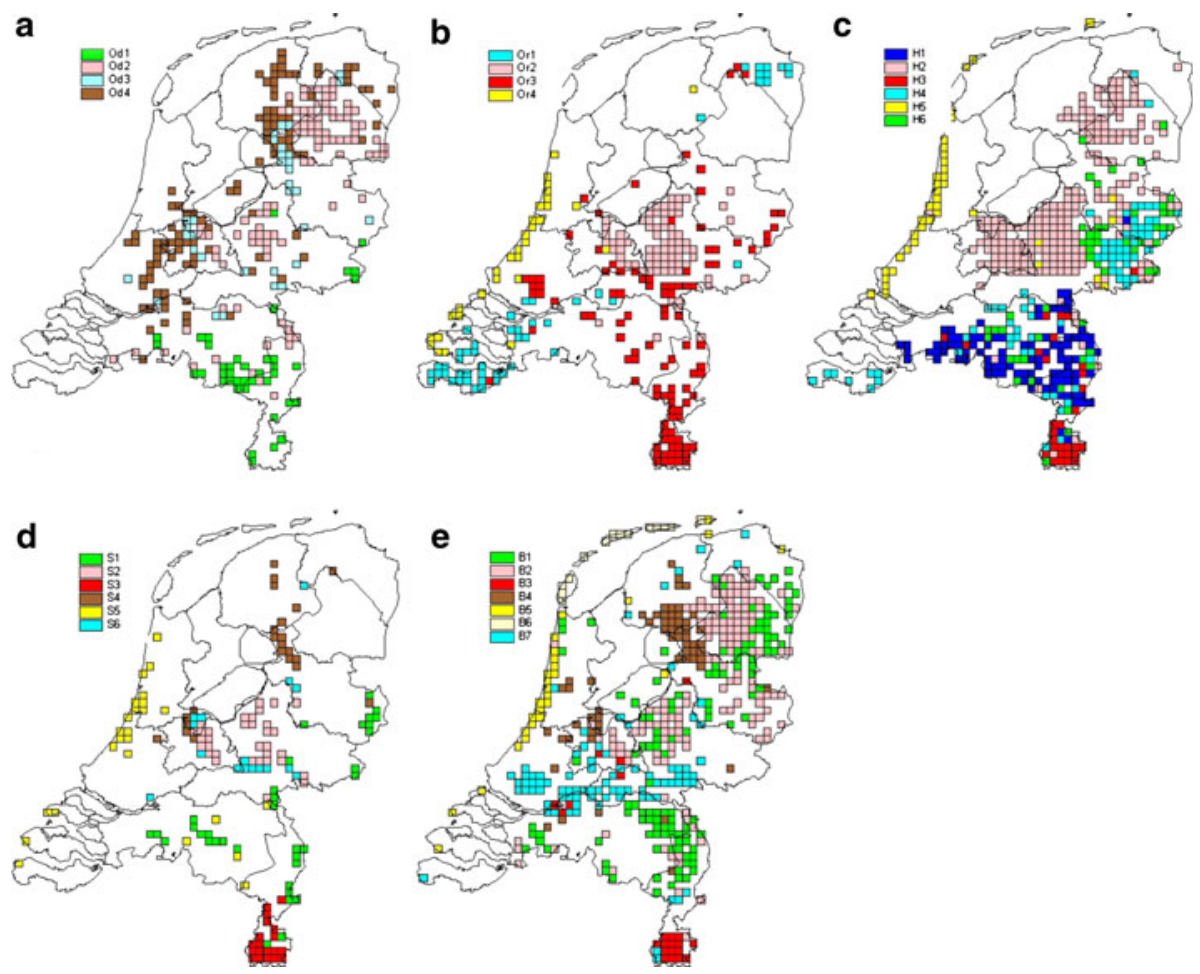

Fig. 1 Selected biogeographical regions with characteristic species per taxonomic group: a dragonflies, b grasshoppers and crickets, $\mathbf{c}$ herpetofauna, $\mathbf{d}$ hoverflies and $\mathbf{e}$ mosses. Codes of the regions in the legends correspond with those of the regions presented and specified in Table 2. (Color figure online)

Describing the hotspots of characteristic species

Altogether, five hotspots of characteristic species were defined (Fig. 2). The first region, forming a narrow band along the North Sea coast (DUNE), hosts four of the five taxonomic groups but its status as a hotspot is based on only a few species. For the mosses, DUNE can be subdivided into a coastal dune region and a Wadden region (the lime-poor northern dune area, including the Frisian islands), the latter subregion having considerably more characteristic species (Table 2). The second region (FEN) is found in the north and central western parts of the country and is a recognized region with characteristic species for three of the five taxonomic groups. The core of the third region (SAND) lies on the Pleistocene sand plateaus in the central and northern parts of the country and is the only region that is congruent for all five taxonomic groups. The fourth region (SE) is confined to the southeastern part of the country and is recognized as a region with characteristic species for all taxa except the grasshoppers and crickets. Finally, the fifth region (LIMB)- the smallest and most distinct one with by far the most characteristic species-is mainly situated in the southern part of the province of Limburg. (See Appendix 2, Fig. 3 for the location of the provinces.) Together these five regions cover about $40 \%$ of the terrestrial surface of the Netherlands.

Four regions are only recognized for single taxonomic groups. While they are briefly discussed here, these regions are left out of the analysis. Among the grasshoppers and 
Table 2 Overview of the biogeographical regions with characteristic species for each taxonomic group

\begin{tabular}{llr}
\hline Region & Location & Characteristic species \\
\hline
\end{tabular}

Dragonflies

Od1 Southeast

Calopteryx virgo $(6.5 ; 72.1)$, Coenagrion hastulatum $(8.56$; 51.2), Cordulegaster boltonii (3.4; 25.6), Gomphus pulchellus (3.89; 86.1), Ischnura pumilio (3.37; 81.4), Orthetrum coerulescens $(9.7 ; 60.5)$, Somatochlora arctica (4.69; 18.6), Somatochlora flavomaculata $(5.67 ; 39.5)$, Sympetrum depressiusculum $(5.53 ; 30.2)$, Sympecma fusca $(6.81 ; 90.7)$

$\begin{array}{ll}\text { Od2 } & \text { Pleistocene sand } \\ \text { Od3 } & \text { Fen area }\end{array}$

Od4 Fen meadow area Grasshoppers and crickets

$\begin{array}{ll}\text { Or1 } & \text { Zeeland } \\ \text { Or2 } & \text { Pleistocene sand }\end{array}$

Or3 S. Limburg

Or4 Coastal dunes

Herpetofauna

$\begin{array}{ll}\text { H1 } & \text { Brabant } \\ \text { H2 } & \text { Pleistocene sand } \\ \text { H3 } & \text { S. Limburg } \\ & \\ \text { H4 } & \text { East and Zeeland } \\ \text { H5 } & \text { Coastal dunes } \\ \text { H6 } & \text { Southeast }\end{array}$

Hoverflies

S1 Southeast

$\mathrm{S} 2$

Pleistocene sand
Aeshna subarctica $(1.58 ; 15.7)$

Aeshna isosceles (3.61; 100), Aeshna viridis (3.82; 61.8), Coenagrion armatum $(0.81 ; 5.9)$, Gomphus flavipes $(0.82$; 20.6), Leucorrhinia pectoralis $(3.4 ; 47.1)$, Libellula fulva (7.23; 85.3), Sympecma paedisca $(2.08 ; 38.2)$

Aeshna viridis $(2.94 ; 55.1)$

Metrioptera roeselii $(4.27 ; 86.2)$

Decticus verrucivorus (2.98; 29.5), Ephippiger ephippiger (6.63; 47.4), Gampsocleis glabra $(4.24 ; 24.4)$, Metrioptera brachyptera $(1.99 ; 82.1)$, Nemobius sylvestris $(6 ; 91)$, Psophus stridulus $(1.12 ; 6.4)$, Stenobothrus lineatus $(6.38 ; 53.8)$, Stenobothrus stigmaticus $(4.07 ; 78.2)$, Tetrix bipunctata $(1.56 ; 9)$

Acheta domesticus (1.09; 57.1), Conocephalus discolor (1.64; 23.5), Meconema meridionale (0.42; 9.2), Phaneroptera falcata $(1.1 ; 22.7)$, Pholidoptera griseoaptera (1.94; 65.5), Tetrix subulata $(1.17 ; 59.7)$, Tetrix tenuicornis $(1.49 ; 18.5)$

Platycleis albopunctata $(9.33 ; 72.5)$, Tetrix ceperoi $(2.96$; 65.9)

Triturus helveticus $(3.59 ; 57.4)$

Coronella austriaca $(0.82 ; 46.9)$, Natrix natrix $(1.05 ; 87.1)$

Alytes obstetricans (11.13; 44.7), Bombina variegata (9.96; $36.8)$, Salamandra salamandra $(4.39 ; 18.4)$

Hyla arborea $(2.68,77.9)$

Lacerta agilis $(3.30$; 98.6)

Pelobates fuscus $(7.93 ; 87.3)$, Hyla arborea (1.60; 63.6)

Ceriana vespiformis $(1.17 ; 5.4)$, Chalcosyrphus piger $(0.75$; 5.4), Cheilosia carbonaria (2.65; 51.4), Chrysogaster rondanii $(2.02 ; 13.5)$, Chrysotoxum verralli $(1.98 ; 35.1)$, Eristalis cryptarum (1.76; 8.1), Paragus majoranae (2.53; 27), Trichopsomyia flavitarsis $(2.86 ; 56.8)$, Xylota abiens $(5.68 ; 73)$, Xylota meigeniana $(2.08 ; 45.9)$

Chrysotoxum octomaculatum (6.2; 72.7), Dasysyrphus pauxillus $(3.04 ; 36.4)$, Didea alneti $(3.54 ; 69.7)$, Doros conopseus $(3.76 ; 51.5)$, Microdon analis $(3.5 ; 66.7)$, Parasyrphus annulatus (3.82; 84.8), Parasyrphus malinellus (3.16; 72.7), Parasyrphus vittiger (2.88; 75.8), Platycheirus discimanus $(3.43 ; 30.3)$, Sphaerophoria virgata $(3.83 ; 57.6)$ 
Table 2 continued

\begin{tabular}{|c|c|c|c|}
\hline Region & Location & Characteristic species & Total \\
\hline $\mathrm{S} 3$ & S. Limburg & $\begin{array}{l}\text { Cheilosia barbata }(23.37 ; 79.2), \text { Cheilosia lenis }(21.71 ; \\
\text { 70.8), Pipizella virens }(20.9 ; 75), \text { Platycheirus parmatus } \\
\text { (18.68; 54.2), Pipizella annulata }(15.86 ; 62.5), \\
\text { Platycheirus tarsalis }(15.81 ; 45.8), \text { Chrysogaster } \\
\text { chalybeata }(14.94 ; 75), \text { Orthonevra nobilis }(14.87 ; 70.8), \\
\text { Criorhina ranunculi }(13.04 ; 58.3), \text { Cheilosia nigripes } \\
(12.93 ; 37.5)\end{array}$ & 77 \\
\hline $\mathrm{S} 4$ & Fen area & $\begin{array}{l}\text { Eristalis anthophorina }(3.74 ; 59.1), \text { Lejogaster tarsata } \\
\text { (1.64; 72.7), Orthonevra geniculata }(5.16 ; 54.5), \\
\text { Orthonevra intermedia }(8.53 ; 81.8), \text { Parhelophilus } \\
\text { consimilis }(7.92 ; 54.5), \text { Platycheirus fulviventris }(1.19 ; \\
\text { 95.5), Platycheirus occultus }(1.87 ; 59.1)\end{array}$ & 7 \\
\hline S5 & Coastal dunes & Brachyopa insensilis $(3.50 ; 36.7)$ & 1 \\
\hline S6 & Gradient & $\begin{array}{l}\text { Cheilosia grossa }(2.36 ; 76.5), \text { Cheilosia semifasciata }(3.68 ; \\
64.7), \text { Cheilosia uviformis }(5.06 ; 58.8), \text { Melanogaster } \\
\text { aerosa }(2.45 ; 41.2), \text { Eristalis similis }(2.41 ; 82.4), \\
\text { Myolepta dubia }(6.54 ; 47.1), \text { Neoascia geniculata }(2.48 ; \\
\text { 70.6), Neoascia interrupta }(4.27 ; 70.6), \text { Parasyrphus } \\
\text { nigritarsis }(3.22 ; 29.4), \text { Pipiza luteitarsis }(6.18 ; 76.5)\end{array}$ & 25 \\
\hline \multicolumn{4}{|l|}{ Mosses } \\
\hline B1 & Southeast & $\begin{array}{l}\text { Atrichum tenellum }(1.8 ; 56.1)), \text { Pogonatum aloides }(1.53 ; \\
\text { 47.2), Pohlia lescuriana }(1.32 ; 36.1), \text { Pohlia } \\
\text { camptotrachela }(1.31 ; 32.7), \text { Pohlia annotina }(1.24 ; 57) \text {, } \\
\text { Dicranum montanum }(1.21 ; 78.5), \text { Philonotis fontana } \\
\text { (1.19; 55.6), Dicranum tauricum }(1.15 ; 43.5), \\
\text { Fossombronia wondraczekii }(0.72 ; 24.8), \text { Pogonatum } \\
\text { urnigerum }(0.67 ; 22.0)\end{array}$ & 25 \\
\hline B2 & Pleistocene sand & $\begin{array}{l}\text { Odontoschisma sphagni }(2.43 ; 65.8), \text { Sphagnum } \\
\text { magellanicum }(2.31 ; 58.1), \text { Sphagnum tenellum }(2.27 ; \\
\text { 56.8), Sphagnum molle }(1.8 ; 47.1), \text { Mylia anomala }(1.61 ; \\
\text { 35.5), Cephalozia connivens }(1.58 ; 68.4), \text { Dicranum } \\
\text { spurium }(1.51 ; 45.8), \text { Cephalozia macrostachya }(1.10 ; \\
\text { 45.5), Barbilophozia kunzeana }(0.93 ; 21.9), \\
\text { Barbilophozia hatcheri }(0.78 ; 20.0)\end{array}$ & 40 \\
\hline B3 & S. Limburg & $\begin{array}{l}\text { Leiocolea bantriensis }(16.54 ; 33.3), \text { Lophocolea minor } \\
\text { (15.36; 45.8), Mnium marginatum }(15.14 ; 70.8), \\
\text { Eurhynchium pumilum }(13.65 ; 66.7), \text { Plagiothecium } \\
\text { cavifolium }(13.24 ; 45.8), \text { Pohlia cruda }(13.02 ; 20.8), \\
\text { Plagiochila asplenioides }(12.36 ; 58.3), \text { Trichostomum } \\
\text { crispulum }(11.6 ; 25), \text { Campylophyllum calcareum }(11.4 ; \\
29.2), \text { Eurhynchium schleicheri }(10.81 ; 33.3)\end{array}$ & 102 \\
\hline B4 & Fen (meadow) area & $\begin{array}{l}\text { Sphagnum teres }(4.75 ; 47.6), \text { Riccardia multifida }(3.02 ; \\
\text { 38.1), Sphagnum contortum }(2.73 ; 25.4), \text { Pallavicinia } \\
\text { lyellii }(2.57 ; 55.6), \text { Sphagnum rubellum }(2.35 ; 54), \\
\text { Rhizomnium pseudopunctatum }(2.2 ; 23.8), \text { Dicranum } \\
\text { bonjeanii }(2.09 ; 58.7), \text { Pellia neesiana }(2 ; 49.2), \\
\text { Plagiomnium ellipticum }(1.86 ; 69.8), \text { Straminergon } \\
\text { stramineum }(1.74 ; 58.7)\end{array}$ & 19 \\
\hline B5 & Coastal dunes & $\begin{array}{l}\text { Tortella flavovirens }(8.71 ; 58.6), \text { Ditrichum flexicaule }(7.45 ; \\
\text { 48.3), Rhodobryum roseum }(4.9 ; 44.8), \text { Bryum provinciale } \\
\quad(4.42 ; 22.4), \text { Rhynchostegium megapolitanum }(4.05 ; 69) \text {, } \\
\text { Pleurochaete squarrosa }(3.34 ; 19), \text { Rhytidium rugosum } \\
(2.98 ; 12.1)\end{array}$ & 7 \\
\hline
\end{tabular}


Table 2 continued

\begin{tabular}{|c|c|c|c|}
\hline Region & Location & Characteristic species & Total \\
\hline B6 & Wadden islands & $\begin{array}{l}\text { Lophozia excisa }(16.78 ; 95), \text { Bryum marratii }(11.65 ; 45), \\
\text { Fossombronia incurva }(11.49 ; 60), \text { Bryum algovicum } \\
(9.48 ; 70), \text { Moerckia hibernica }(8.7 ; 30), \text { Bryum warneum } \\
(8.62 ; 45), \text { Campyliadelphus elodes }(8.24 ; 50), \\
\text { Drepanocladus sendtneri }(8.06 ; 40), \text { Riccardia incurvata } \\
(7.82 ; 75), \text { Campylopus fragilis }(3.39 ; 25.0)\end{array}$ & 55 \\
\hline B7 & Rivers & $\begin{array}{l}\text { Cinclidotus fontinaloides }(4.09 ; 52.2), \text { Fissidens crassipes } \\
\text { (4.02; 45.7), Cinclidotus riparius }(3.95 ; 50), \text { Schistidium } \\
\text { platyphyllum }(3.7 ; 48.9), \text { Didymodon sinuosus }(3.67 ; \\
\text { 44.6), Leskea polycarpa }(2.98 ; 77.2) \text {, Orthotrichum } \\
\text { cupulatum }(2.71 ; 43.5), \text { Syntrichia latifolia }(2.7 ; 58.7), \\
\text { Cinclidotus danubicus }(2.61 ; 29.4), \text { Amblystegium } \\
\text { fluviatile }(2.51 ; 45.7)\end{array}$ & 24 \\
\hline
\end{tabular}

Characteristic species are listed for each region up to a maximum of 10 . Preference index and the frequency of a species (\% of grid squares in which it occurs) in the region are given in parentheses. The total number of characteristic species for each region is given in the last column. Nomenclature of the regions corresponds with that of the regions in Fig. 1

crickets, the occurrence of Metrioptera roeselii separated 65 grid squares in the southwestern province of Zeeland. Based on the distribution of the herpetofauna (Hyla arborea) a somewhat similar region could be designated, but this region has a major extension in the eastern part of the country. Twenty-five species of hoverfly (e.g., Cheilosia grossa, Cheilosia semifasciata, Cheilosia uviformis) distinguished a region of 16 grid squares, largely following the gradient between the lower parts of the Netherlands and the Pleistocene sand plateau. Regarding the mosses, 92 grid squares along the Rhine and Meuse Rivers form a region characterized by 24 species (e.g., Cinclidotus fontinaloides, Fissidens crassipes, Cinclidotus riparius).

\section{Environmental differentiation}

The results of the stepwise discriminant analysis indicate that the five hotspots of characteristic species differ significantly with regard to their environmental conditions (Wilks' lambda $=0.019 ; P<0.001)$. Four discriminant functions were constructed and 21 environmental variables (Table 4) were selected from the input list of 33 possible determining variables (Appendix 1) in order to explain the variation among five hotspots.

The first discriminant function indicates that there is a big difference between the DUNE and LIMB regions on the one hand and the SAND and SE regions on the other. This difference is marked by the higher amount of radiation the DUNE and LIMB regions receive on an annual basis, as well as by the higher $\mathrm{pH}$ of associated soils. The DUNE region clearly stands out, as it receives more sunshine annually than the other regions (see Appendix 1, Table 5). Higher elevation, a high percentage of non-calcareous loamy soils, and the low groundwater level in spring imply that the second function separates LIMB from all other regions. The third function isolates the FEN region from the others, as a large proportion of the grid squares that make up the FEN region consist of freshwater and the grid squares are largely situated on peat soil. The fourth function is less robust but separates the SAND from the SE region. The SAND region has a relatively low mean annual temperature and a slightly higher precipitation surplus, whereas the SE region receives a considerably higher deposition of nitrogen each year than the other regions. 
Table 3 Kappa statistics for the regions with characteristic species

\begin{tabular}{lllll}
\hline (a) Coastal dune regions (DUNE) & & & \\
\hline & H5 & B5 and B6 & S5 \\
\hline H5 & 1 & & & \\
B5 and B6 & 0.489 & 1 & 1 & 1 \\
S5 & 0.290 & 0.303 & 0.382 & 1 \\
Or4 & 0.460 & 0.422 & & \\
\hline
\end{tabular}

(b) Fen area regions (FEN)

\begin{tabular}{llll}
\hline & B4 & S4 & Od3 and Od4 \\
\hline B4 & 1 & & \\
S4 & 0.386 & 1 & 1 \\
Od3 and Od4 & 0.297 & 0.207 & 1 \\
\hline
\end{tabular}

(c) Pleistocene sand regions (SAND)

\begin{tabular}{llllll}
\hline & H2 & B2 & S2 & Or2 & Od2 \\
\hline H2 & 1 & & & & \\
B2 & 0.374 & 1 & & & \\
S2 & 0.212 & 0.126 & 1 & 0.174 & 1 \\
Or2 & 0.397 & 0.173 & 0.457 & 0.141 & \\
Od2 & 0.279 & 0.416 & & & \\
\hline
\end{tabular}

(d) Southeastern regions (SE)

\begin{tabular}{lllll}
\hline & H1 and H6 & B1 & S1 & Od1 \\
\hline H1 and H6 & 1 & & & \\
B1 & 0.283 & 1 & & \\
S1 & 0.179 & 0.158 & 1 & \\
Od1 & 0.267 & 0.140 & 0.250 & 1 \\
\hline
\end{tabular}

(e) Limburg regions (LIMB)

\begin{tabular}{lllll}
\hline & H3 & B3 & S3 & Or3 \\
\hline H3 & 1 & & & \\
B3 & 0.442 & 1 & & \\
S3 & 0.422 & 0.552 & 1 & 1 \\
Or3 & 0.240 & 0.205 & 0.229 & 1 \\
\hline
\end{tabular}

Nomenclature of the regions corresponds with that of the regions in Table 2 and Fig. $1 .<0.2$ represents poor agreement, 1 very good

Reclassification of the original data with SDA in order to validate the outcomes of the initial analysis produced the following results. Using the 21 selected environmental variables and the four discriminate functions derived from the initial analysis, $81.9 \%$ of all grid squares could be allocated to the region they were assigned to during the initial analysis. A posteriori classification produced most satisfactory results for the DUNE (85.9\%) and SE (84.5\%) regions and a somewhat weaker fit for the LIMB (80.8\%), SAND (79.6\%), and FEN (79.1\%) regions. 
a DUNE
$\square$
$\square^{1}$
$\square^{3}$
$\nabla^{2}$
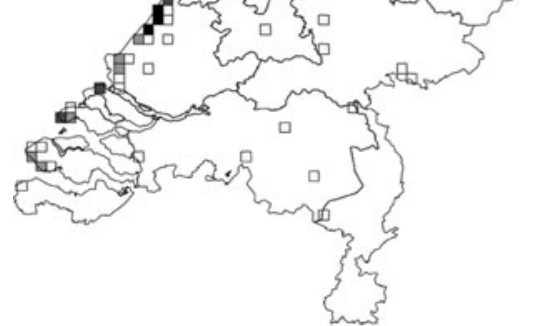

C $\begin{array}{r}\text { SAND } \\ \nabla^{1} \\ 3 \\ \nabla^{4} \\ 5\end{array}$

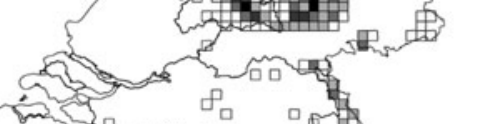

(mins

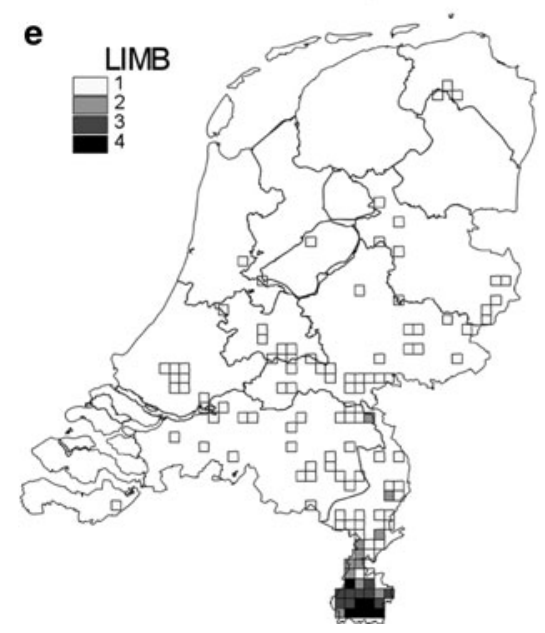

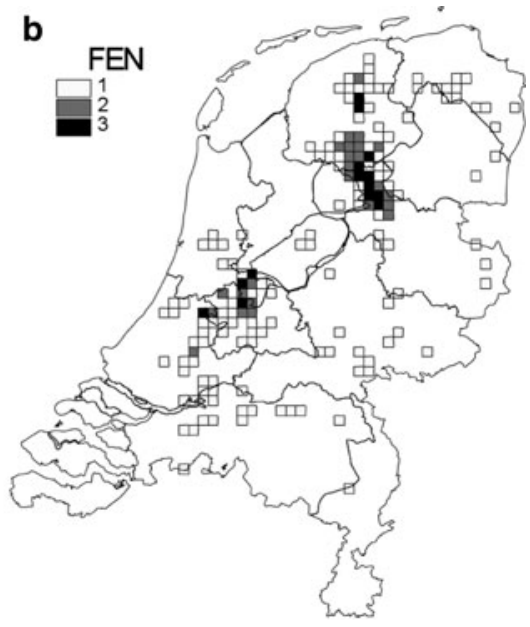
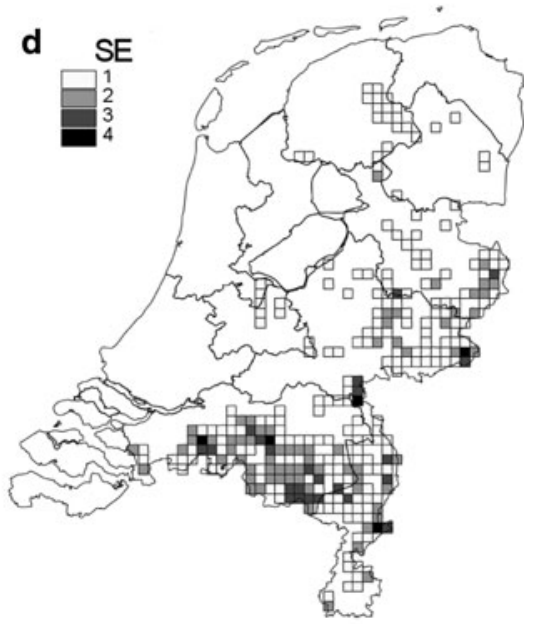
Fig. 2 Hotspots of characteristic species. Regionalization of the Netherlands based on the distribution of species from five taxonomic groups that have a high degree of fidelity to each region. Numbers refer to the number of taxonomic groups for which a grid square is allocated to the regions: a DUNE; b FEN; c SAND; d SE; and e LIMB. For abbreviations, see Table 3

Table 4 Summary of the stepwise discriminant analysis

\begin{tabular}{|c|c|c|c|c|c|c|}
\hline & & \multicolumn{5}{|c|}{ Factor loadings } \\
\hline & & DF 1 & & DF 2 & DF 3 & DF 4 \\
\hline \multicolumn{2}{|c|}{ Precipitation surplus } & -0.224 & & -0.095 & 0.198 & 0.539 \\
\hline \multicolumn{2}{|c|}{ Relative humidity in spring } & 0.335 & & -0.338 & 0.341 & 0.297 \\
\hline \multicolumn{2}{|c|}{ Amount of radiation } & 0.723 & & -0.097 & -0.156 & -0.106 \\
\hline \multicolumn{2}{|c|}{ Duration of sunshine } & $\mathbf{0 . 5 3 3}$ & & -0.29 & 0.175 & 0.18 \\
\hline \multicolumn{2}{|c|}{ Temperature } & 0.276 & & 0.152 & -0.247 & -0.441 \\
\hline \multicolumn{2}{|c|}{ Elevation } & -0.043 & & 0.672 & -0.169 & 0.223 \\
\hline \multicolumn{2}{|c|}{ Groundwater table in spring } & -0.081 & & 0.429 & -0.326 & 0.392 \\
\hline \multicolumn{2}{|c|}{ Salinity } & 0.258 & & -0.264 & 0.16 & 0.066 \\
\hline \multicolumn{2}{|l|}{$\mathrm{pH}$} & 0.415 & & 0.083 & 0.273 & $-\mathbf{0 . 4 3 1}$ \\
\hline \multicolumn{2}{|c|}{ Nitrogen deposition } & -0.337 & & 0.095 & -0.275 & -0.409 \\
\hline \multicolumn{2}{|c|}{ Non-calcareous loam } & 0.177 & & 0.756 & 0.081 & 0.181 \\
\hline \multicolumn{2}{|c|}{ Calcareous sandy soils } & 0.395 & & -0.167 & -0.227 & 0.137 \\
\hline \multicolumn{2}{|c|}{ Non-calcareous clay } & 0.116 & & 0.032 & 0.276 & -0.128 \\
\hline \multicolumn{2}{|c|}{ Calcareous clay } & 0.097 & & -0.053 & 0.059 & -0.128 \\
\hline \multicolumn{2}{|c|}{ Peat soil } & 0.017 & & -0.109 & 0.579 & -0.091 \\
\hline \multicolumn{2}{|c|}{ Rich sandy soils } & -0.265 & & -0.022 & -0.306 & -0.171 \\
\hline \multicolumn{2}{|c|}{ Coniferous forest } & -0.223 & & -0.039 & -0.194 & 0.338 \\
\hline \multicolumn{2}{|c|}{ Freshwater } & 0.107 & & -0.069 & 0.437 & -0.216 \\
\hline \multicolumn{2}{|c|}{ Agricultural areas } & -0.104 & & 0.043 & 0.189 & -0.247 \\
\hline \multicolumn{2}{|l|}{ Marsh } & 0.056 & & -0.055 & 0.345 & -0.115 \\
\hline \multicolumn{2}{|c|}{ Fen areas } & 0.013 & & -0.017 & 0.116 & -0.052 \\
\hline \multirow[t]{2}{*}{ Region } & \multicolumn{6}{|l|}{ Centroid } \\
\hline & \multicolumn{2}{|l|}{ DF 1} & \multicolumn{2}{|l|}{ DF 2} & DF 3 & DF 4 \\
\hline \multirow{2}{*}{$\begin{array}{l}\text { DUNE } \\
\text { FEN }\end{array}$} & 4.503 & \multicolumn{3}{|c|}{-1.469} & -1.146 & 0.495 \\
\hline & 0.713 & & -0.703 & & 2.095 & -0.449 \\
\hline SAND & -1.292 & & -0.31 & & -0.098 & 1.015 \\
\hline SE & -0.636 & & 0.245 & & -0.704 & -0.987 \\
\hline LIMB & 2.276 & & 7.228 & & 0.5 & 0.715 \\
\hline
\end{tabular}

Factor loadings indicate the degree of correlation of the environmental variables with the discriminant functions (DF). High factor loadings $(>0.4$ or $<-0.4)$ are given in bold. The position of the centroid (the point that represents the means for all variables in the multivariate space defined by the model) of each region is indicated relative to each discriminant function

\section{Discussion}

Despite the lack of endemic species or a clear distinction in species richness, we were able to identify major regions in the Netherlands warranting a high conservation priority in light of their biodiversity. By incorporating five distinct groups of species displaying a wide 
range of life strategies, the regions defined in this study represent more generalized patterns. Thereby, this study adds important information to the regions based on single taxa already described. All the regions that we defined as hotspots have a distinct composition of species from several taxonomic groups. These regions are complementary in the sense that they all comprise species that do not (or only sparsely) occur in other parts of the country. For the five species groups studied here, these regions comprise the majority of the species present in the Netherlands, since these regions automatically incorporate the more common and widely distributed species too. This phenomenon of nestedness in species composition was observed earlier for Orthoptera in the Netherlands (Schouten et al. 2007).

The patterns we present here reflect a long time span (1850-2003). Species distribution ranges are, of course, not static. It may well be that, among the species we identified as characteristic of a certain region, there are species whose distribution ranges are currently expanding as a consequence of climate change. For several of the grasshopper and cricket species (Conocephalus discolor, Phaneroptera falcata, Conocephalus discolor) we have reason to assume this is the case. We are also aware of the limitations of the databases used in this study. For some species these databases probably do not give an accurate representation of their distributional ranges, due to lack of data. Were more data on the distribution of these species available, those currently identified as characteristic species could turn out to be more common than previously assumed. This underlines the importance of keeping distributional data up to date and of striving for maximum geographic coverage.

\section{Differences among the hotspots of characteristic species}

Stepwise discriminant analysis revealed significant environmental differences among the five hotspots. The regions appear to differ according to elevation, soil type, soil chemistry, and climate - the physical conditions most important to biodiversity (Schouten et al. 2009). There proved to be a big difference between regions in the eastern Pleistocene and those in the western Holocene parts of the Netherlands (see Appendix 2, Fig. 3 for locations). The Holocene parts (including the DUNE and FEN regions) are characterized by a low elevation and a high amount of sunshine. The eastern Pleistocene parts (including SAND, SE, and LIMB) receive higher levels of precipitation, as large sections are situated on an icepushed sand plateau with hills. The SAND region is characterized by many boreal species. The SE region contains many central European species. The southern LIMB region stands out in every respect; with its aberrant soil type and relatively high hills it cannot be compared with any other region in the Netherlands. The majority of species occurring in the LIMB region have their origin in southern Europe. The five regions showed differentiation in climatic conditions (temperature, amount of radiation, and precipitation surplus). Therefore, changes in temperature and precipitation regimes as a consequence of climate change are expected to have a strong influence on the future species composition of the Netherlands. In fact, the first signs of this process have already been observed (Tamis et al. 2005). The amount of nitrogen deposition also showed a strong correlation with the spatial organization of the regions. If nitrogen deposition acts as a strong driver of change in species composition, this could be an indication that human activity can easily, and within a time span of several decades, overrule historic biogeographical patterns.

\section{Distinguishing features of the characteristic species}

Species are deemed characteristic when their optimal distribution lies in a specific region. This means that, potentially, the species identified here as characteristic species warrant 
protection as they depend on a restricted part of the country for their existence. In general, species with a limited distribution range are more vulnerable to disturbance than species that have a broader range. And in fact the very existence of many of the species designated as characteristic species is under threat. The herpetofauna species we depicted as characteristic species are all included on the Red List of Threatened Species compiled by the IUCN (International Union for Conservation of Nature and Natural Resources), under the categories of critically endangered (1 species), endangered (5 species), or vulnerable (4 species). For the mosses, almost half of the characteristic species appear on the Red List of Threatened Species. For the grasshoppers and crickets, 7 of the 19 characteristic species are on the Red List. All seven of the dragonfly species identified as being characteristic of the FEN region are included on the Dutch Red List while four of them are also included in the EU Habitats Directive. A Red List of hoverfly species is currently not available. This certainly does not mean that hoverfly species are facing less threat than species that are legally protected; actually, several of the species we identified as characteristic species are rare and/or currently declining (Reemer et al. 2009).

\section{Comparison with other regions}

A regionalization of the Netherlands already exists for vascular plants (Weeda 1990) and breeding birds (Kwak and van den Berg 2004). Based on the distribution of vascular plant species, 22 phytogeographical districts can be recognized for the Netherlands. According to the distribution of breeding bird species, the Netherlands can be divided into 18 separate districts. A general notion in ecology is that faunistic distributions may follow those of vegetation, as vegetation provides habitat for animals, birds, and insects. Sjörs (1965) suggested that especially in northern Europe, where there are few dispersal barriers and little endemism, there should be a high degree of similarity between faunistic regions and vegetation zones. There are indeed a number of similarities between the phytogeographical districts and the regions distinguished in this study. A dune district, a fen district (though less extended in the multi-taxon analysis), and the southern Limburg district are distinguished within both classifications. However, in certain regions, the phytogeographical districts differ in a fundamental way from the multi-taxon regions. The phytogeographical partitioning of the Pleistocene sand plateaus into two separate districts is not confirmed by the multi-taxon approach. Also Brabant and the central southeastern part of the country are, according to the multi-taxon analysis, not as different as the phytogeographical districts indicate. Furthermore, the division of the dune region into a phytogeographical Wadden and Renodunaal district is only present in the distribution of moss species. This can be explained by the fact that both vascular plants and mosses have a much stronger link with physical conditions than fauna has. The major difference between the breeding bird districts and the multi-taxon regions concerns the fen areas. According to distributional patterns of breeding bird species, the fen areas of Noord-Holland and Utrecht can be distinguished as a separate region, different from the fen areas of Friesland and Groningen. However, rigorous comparison of these different classifications remains difficult, as the aims and methods as well as the levels of classification differ.

Implications for nature conservation

Biogeographical regions should have characteristic species, correspond to a restricted range of environments, and show a certain degree of geographical congruence (Carey et al. 1995). Therefore, biogeographical classifications comprise a useful framework for the 
conservation of biodiversity (Whitehead et al. 1992; Palmer 1999; Whittaker et al. 2005). In this study we were able to identify five regions in the Netherlands that meet these requirements. Therefore, in order to efficiently capture the wide spectrum of Dutch biodiversity, these multi-taxon hotspots of characteristic species should be well represented in nature conservation policy, notably within the National Ecological Network. Nature conservation should be concerned with the wider sustainable processes and conditions in ecosystems rather than being narrowly fixated on some species of special interest.

Together, the five regions containing unique species cover about $40 \%$ of the country's surface. This fact does not imply that the other $60 \%$ has no conservation value. For example, few of the characteristic species traced in this study are exclusive to a single region; most of them also occur, though rather sparsely, in other parts of the country. Following the methodological principles of robustness and generalizability, we looked for congruence across the distribution patterns of five species groups and selected only those regions where at least two of the groups were represented. As a consequence, the riverine region in the south of Gelderland for example, was not included in our selection; although it contains several characteristic moss species.

The number of characteristic species in each region varied. The small LIMB region hosts by far the highest number of characteristic species. However, the species occurring there are not of great international importance. Being submarginal species in the Netherlands, their distribution is much larger in southern or central Europe. The FEN region, in contrast, is not characterized by many species but is very important from an international perspective, as many of these species depend largely on the Netherlands for their existence (Reemer et al. 2009). Dutch policy on nature conservation should therefore concentrate more of its efforts on this area. This example highlights the need for an evaluation at a higher (Europe-wide) level to assess the importance of different species and regions.

Acknowledgements We are grateful to Nienke van Geel for digitizing the climate maps and to Jolijn Radix, Marja Seegers, and Anouk Cormont for constructing the map of Dutch landscape age. We thank Peter de Ruiter, Nancy Smyth and two anonymous reviewers for their comments on the manuscript.

Open Access This article is distributed under the terms of the Creative Commons Attribution Noncommercial License which permits any noncommercial use, distribution, and reproduction in any medium, provided the original author(s) and source are credited.

\section{Appendix 1}

See Table 5.

Table 5 Mean values $( \pm$ SD) of the 33 possible discriminatory environmental variables used in the stepwise discriminant analysis for the different biogeographical regions with characteristic species

\begin{tabular}{|c|c|c|c|c|c|}
\hline Variables & $\begin{array}{l}\text { DUNE } \\
(n=64)\end{array}$ & $\begin{array}{l}\text { FEN } \\
(n=115)\end{array}$ & $\begin{array}{l}\text { SAND } \\
(n=221)\end{array}$ & $\begin{array}{l}\mathrm{SE} \\
(n=226)\end{array}$ & $\begin{array}{l}\text { LIMB } \\
(n=26)\end{array}$ \\
\hline Elevation (m) & $1.7 \pm 3.4$ & $0.5 \pm 3.7$ & $16.6 \pm 15.4$ & $16.6 \pm 11.6$ & $89.2 \pm 51.8$ \\
\hline $\begin{array}{l}\text { Groundwater table in spring } \\
\text { ( } \mathrm{m} \text { below sea level) }\end{array}$ & $0.7 \pm 0.3$ & $0.4 \pm 0.2$ & $0.9 \pm 0.4$ & $0.8 \pm 0.2$ & $1.7 \pm 0.4$ \\
\hline $\mathrm{pH}$ & $6.2 \pm 0.5$ & $6.1 \pm 0.5$ & $5 \pm 0.5$ & $5.6 \pm 0.5$ & $6.3 \pm 0.4$ \\
\hline
\end{tabular}


Table 5 continued

\begin{tabular}{|c|c|c|c|c|c|}
\hline Variables & $\begin{array}{l}\text { DUNE } \\
(n=64)\end{array}$ & $\begin{array}{l}\text { FEN } \\
(n=115)\end{array}$ & $\begin{array}{l}\text { SAND } \\
(n=221)\end{array}$ & $\begin{array}{l}\mathrm{SE} \\
(n=226)\end{array}$ & $\begin{array}{l}\text { LIMB } \\
(n=26)\end{array}$ \\
\hline $\begin{array}{l}\text { Nitrogen deposition } \\
\text { (mol/ha per year) }\end{array}$ & $1564.4 \pm 636$ & $1960 \pm 418$ & $2295.8 \pm 431.4$ & $2677.5 \pm 486.5$ & $2048.5 \pm 279.8$ \\
\hline $\begin{array}{l}\text { Available nitrogen } \\
\left(\mathrm{g} / \mathrm{m}^{2}\right)\end{array}$ & $5.9 \pm 2$ & $7.1 \pm 1.3$ & $4.6 \pm 1.9$ & $6 \pm 1.5$ & $7.1 \pm 1.1$ \\
\hline Salinity (mg/l) & $0.4 \pm 0.2$ & $0.4 \pm 0.2$ & $0.3 \pm 0.1$ & $0.2 \pm 0.1$ & $0.1 \pm 0.1$ \\
\hline $\begin{array}{l}\text { Dominant landscape } \\
\text { age }^{\mathrm{a}}\end{array}$ & $4.6 \pm 3.7$ & $4.1 \pm 2.5$ & $2.7 \pm 2.4$ & $5.8 \pm 2.9$ & $5.6 \pm 2.9$ \\
\hline $\begin{array}{l}\text { Relative humidity } \\
\text { in spring }(\%)\end{array}$ & $81.3 \pm 1.5$ & $80.1 \pm 1.4$ & $78.3 \pm 1.8$ & $77.1 \pm 1.6$ & $76.3 \pm 0.5$ \\
\hline $\begin{array}{l}\text { Duration of sunshine } \\
\text { (h) }\end{array}$ & $1609.4 \pm 47.9$ & $1535 \pm 44.5$ & $1482.5 \pm 33.4$ & $1471.2 \pm 43.7$ & $1473.1 \pm 17.2$ \\
\hline $\begin{array}{l}\text { Amount of radiation } \\
\left(\mathrm{J} \text { oule } / \mathrm{m}^{2}\right)\end{array}$ & $37.2 \pm 1.0$ & $35.4 \pm 0.7$ & $34.7 \pm 0.3$ & $35.1 \pm 0.6$ & $35.7 \pm 0.2$ \\
\hline Temperature $\left({ }^{\circ} \mathrm{C}\right)$ & $9.9 \pm 0.4$ & $9.5 \pm 0.3$ & $9.3 \pm 0.2$ & $9.7 \pm 0.3$ & $9.9 \pm 0.1$ \\
\hline $\begin{array}{l}\text { Precipitation surplus } \\
\quad(\mathrm{mm})\end{array}$ & $216.9 \pm 37.2$ & $252.7 \pm 25.7$ & $282.8 \pm 45.3$ & $227.8 \pm 39.5$ & $221.5 \pm 38.3$ \\
\hline Poor sandy soils $\left(\mathrm{km}^{2}\right)$ & $3.1 \pm 4.0$ & $3.3 \pm 5.6$ & $12.4 \pm 7.1$ & $7.9 \pm 5.7$ & $1.0 \pm 2.3$ \\
\hline Rich sandy soils $\left(\mathrm{km}^{2}\right)$ & $1.5 \pm 2.8$ & $2.4 \pm 4.4$ & $7.5 \pm 6.1$ & $9.3 \pm 6.0$ & $0.7 \pm 2.2$ \\
\hline $\begin{array}{l}\text { Calcareous sandy soils } \\
\left(\mathrm{km}^{2}\right)\end{array}$ & $5.1 \pm 5.4$ & $0.4 \pm 1.5$ & $0.1 \pm 0.5$ & $0.2 \pm 0.6$ & $0.1 \pm 0.4$ \\
\hline $\begin{array}{l}\text { Non-calcareous clay } \\
\left(\mathrm{km}^{2}\right)\end{array}$ & $2.9 \pm 4.2$ & $5.4 \pm 5.8$ & $1.2 \pm 3.5$ & $2.0 \pm 3.5$ & $4.8 \pm 5.4$ \\
\hline Calcareous clay $\left(\mathrm{km}^{2}\right)$ & $2.6 \pm 4.9$ & $2.3 \pm 5.5$ & $0.3 \pm 1.7$ & $1.3 \pm 3.6$ & $0.4 \pm 0.7$ \\
\hline $\begin{array}{l}\text { Non-calcareous loam } \\
\left(\mathrm{km}^{2}\right)\end{array}$ & $0.0 \pm 0$ & $0.0 \pm 0$ & $0.1 \pm 0.4$ & $0.32 \pm 1.3$ & $11.5 \pm 8.3$ \\
\hline Peat soils $\left(\mathrm{km}^{2}\right)$ & $0.4 \pm 0.9$ & $6.9 \pm 7.2$ & $1.6 \pm 2.6$ & $0.8 \pm 2.1$ & $0.2 \pm 0.8$ \\
\hline $\begin{array}{l}\text { Heterogeneity of } \\
\text { landscape types }(\mathrm{H})\end{array}$ & $1.3 \pm 0.3$ & $1.2 \pm 0.3$ & $1.4 \pm 0.2$ & $1.4 \pm 0.3$ & $1.3 \pm 0.2$ \\
\hline $\begin{array}{l}\text { Agricultural areas } \\
\left(\mathrm{km}^{2}\right)\end{array}$ & $8.4 \pm 6.7$ & $15.8 \pm 5.1$ & $12.6 \pm 6.8$ & $14.6 \pm 5.0$ & $13.4 \pm 5.1$ \\
\hline Urbanized areas $\left(\mathrm{km}^{2}\right)$ & $6.4 \pm 5.7$ & $4.2 \pm 3.8$ & $3.6 \pm 3.2$ & $5.0 \pm 4.3$ & $7.5 \pm 4.7$ \\
\hline $\begin{array}{l}\text { Deciduous forest } \\
\left(\mathrm{km}^{2}\right)\end{array}$ & $1.5 \pm 1.7$ & $0.5 \pm 0.6$ & $1.9 \pm 1.3$ & $1.5 \pm 0.9$ & $1.5 \pm 0.8$ \\
\hline $\begin{array}{l}\text { Coniferous forest } \\
\left(\mathrm{km}^{2}\right)\end{array}$ & $5.1 \pm 1.0$ & $0.1 \pm 0.4$ & $4.2 \pm 4.6$ & $2.0 \pm 2.4$ & $0.2 \pm 0.9$ \\
\hline Salt marshes $\left(\mathrm{km}^{2}\right)$ & $0.1 \pm 0.4$ & $0.0 \pm 0$ & $0.0 \pm 0$ & $0.0 \pm 0$ & $0.0 \pm 0$ \\
\hline Dune vegetation $\left(\mathrm{km}^{2}\right)$ & $2.9 \pm 3.8$ & $0.0 \pm 0$ & $0.0 \pm 0$ & $0.0 \pm 0$ & $0.0 \pm 0$ \\
\hline Heath $\left(\mathrm{km}^{2}\right)$ & $0.0 \pm 0$ & $0.0 \pm 0$ & $1.0 \pm 1.9$ & $0.2 \pm 0.6$ & $0.0 \pm 0$ \\
\hline Peat bog $\left(\mathrm{km}^{2}\right)$ & $0.0 \pm 0$ & $0.0 \pm 0$ & $0.1 \pm 1.1$ & $0.1 \pm 0.7$ & $0.0 \pm 0$ \\
\hline $\begin{array}{l}\text { Sedge vegetation } \\
\left(\mathrm{km}^{2}\right)\end{array}$ & $0.00 \pm 0$ & $0.5 \pm 1.3$ & $0.0 \pm 0$ & $0.0 \pm 0$ & $0.0 \pm 0$ \\
\hline $\operatorname{Marsh}\left(\mathrm{km}^{2}\right)$ & $0.1 \pm 0.2$ & $0.6 \pm 1.3$ & $0.0 \pm 0$ & $0.0 \pm 0$ & $0.0 \pm 0$ \\
\hline Fen areas $\left(\mathrm{km}^{2}\right)$ & $0.0 \pm 0$ & $0.1 \pm 0.6$ & $0.0 \pm 0$ & $0.0 \pm 0$ & $0.0 \pm 0$ \\
\hline $\begin{array}{l}\text { Other natural areas } \\
\left(\mathrm{km}^{2}\right)\end{array}$ & $0.2 \pm 1.3$ & $0.5 \pm 0.7$ & $0.8 \pm 0.8$ & $0.4 \pm 0.5$ & $0.1 \pm 0.1$ \\
\hline Freshwater $\left(\mathrm{km}^{2}\right)$ & $0.9 \pm 1.6$ & $2.6 \pm 3.0$ & $0.3 \pm 0.6$ & $0.6 \pm 0.9$ & $0.6 \pm 1.1$ \\
\hline
\end{tabular}


Table 5 continued

\begin{tabular}{llllll}
\hline Variables & $\begin{array}{l}\text { DUNE } \\
(n=64)\end{array}$ & $\begin{array}{l}\text { FEN } \\
(n=115)\end{array}$ & $\begin{array}{l}\text { SAND } \\
(n=221)\end{array}$ & $\begin{array}{l}\text { SE } \\
(n=226)\end{array}$ & $\begin{array}{l}\text { LIMB } \\
(n=26)\end{array}$ \\
\hline Nature $(\%)$ & $5.3 \pm 4.8$ & $2.3 \pm 2.5$ & $8.2 \pm 6.7$ & $4.2 \pm 3.2$ & $1.9 \pm 1.2$ \\
\hline
\end{tabular}

$n=$ number of $5 \times 5 \mathrm{~km}$ squares included in each region

a Eleven landscape age classes were defined: 1 (1000-1299); 2 (1300-1499) 3 (1500-1700); 4 (1701-1800); 5 (1801-1850); 6 (1851-1900); 7 (1901-1920); 8 (1921-1940); 9 (1941-1960); 10 (1961-1990); 11 (19912004). Dates reflect the last major shift in land cover

\section{Appendix 2}

See Fig. 3.

Fig. 3 Map of the Netherlands, provinces indicated, gray Pleistocene and older, rest Holocene

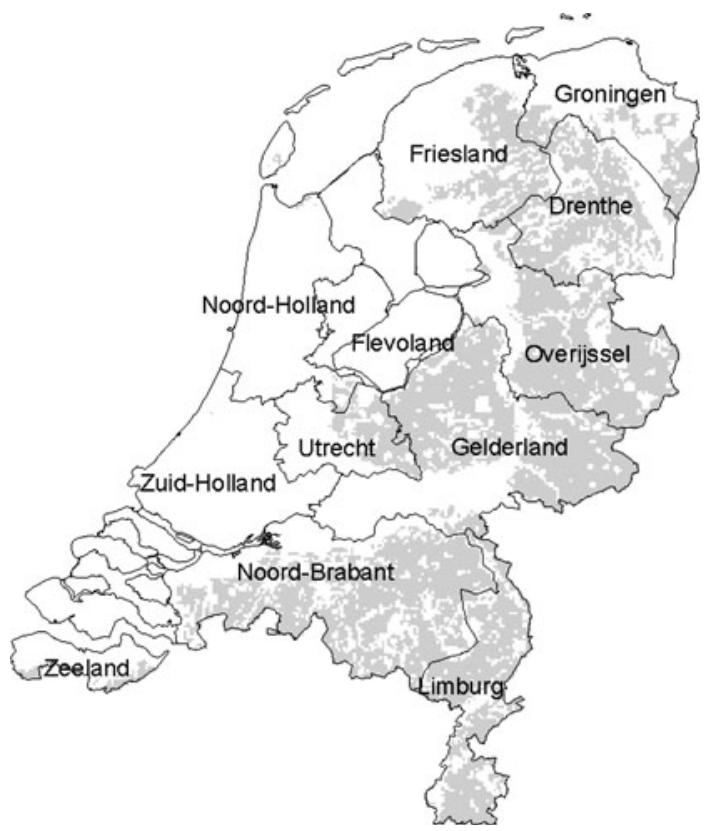

\section{References}

Alterra (2001) Het Landelijk grondgebruiksbestand Versie 4 (LGN4). Centrum voor Geo-informatie, Wageningen

Andelman SJ, Fagan WF (2000) Umbrellas and flagships: efficient conservation surrogates or expensive mistakes? Proc Natl Acad Sci USA 97:5954-5959

Beuk PLTh (ed) (2002) Checklist of the Diptera of the Netherlands. KNNV Uitgeverij, Utrecht

Bio AMF, Alkemade A, Barendregt A et al (1999) Geostatistical interpolation of abiotic site conditions in the Netherlands. A method for reference mapping. RIVM report 408657 003. RIVM, Bilthoven

Carey PD, Preston CD, Hill MO et al (1995) An environmentally defined biogeographical zonation of Scotland designed to reflect species distributions. J Ecol 83:833-845

Cormont A, Radix J, Segers M (2004) The spatial distribution of biodiversity over the Netherlands: the role of landscape age. Internal research project MSc Natural Resources Management, Utrecht University 
Diffendorfer JE, Fleming GM, Duggan JM et al (2007) Developing terrestrial, multi-taxon indices of biological integrity: an example from coastal sage scrub. Biol Conserv 140:130-141

Dûfrene M, Legendre P (1997) Species assemblages and indicator species: the need for a flexible asymetrical approach. Ecol Monogr 67:345-366

Faith DP, Carter G, Cassis G et al (2003) Complementarity, biodiversity viability analysis, and policy-based algorithms for conservation. Environ Sci Policy 6:311-328

Fox NJ, Beckley LE (2005) Priority areas for conservation of Western Australian coastal fishes: a comparison of hotspot, biogeographical and complementarity approaches. Biol Conserv 125:399-410

Guralnick R, Van Cleve J (2005) Strengths and weaknesses of museum and national survey data sets for predicting regional species richness: comparative and combined approaches. Divers Distrib 11: 349-359

Hill MO (1979) TWINSPAN: a Fortran program for arranging multivariate data in an ordered two-way table of the individuals and attributes. Cornell University Press, New York

Jepson P, Canney S (2001) Biodiversity hotspots: hot for what? Glob Ecol Biogeogr 10:225-227

Kati V, Devillers P, Dufrêne M et al (2004) Testing the value of six taxonomic groups as biodiversity indicators at a local scale. Conserv Biol 18:667-675

Kleukers RMJC, van Nieukerken EJB, Odé LPM et al (1997) De sprinkhanen en krekels van Nederland: Orthoptera. Nederlandse Fauna 1. Nationaal Natuurhistorisch Museum Naturalis, KNNV Uitgeverij \& European Invertebrate Survey, Leiden

KNMI (2002) Klimaatatlas van Nederland. Elmar, B.V., Rijswijk

Kwak RGM, van den Berg A (2004) Nieuwe Broedvogeldistricten van Nederland. Alterra report 1006. Alterra, Wageningen

Landis JR, Koch G (1977) The measurement of observer agreement for categorical data. Biometrics 33: 159-174

Maes D, Bonte D (2007) Using distribution patterns of five threatened invertebrates in a highly fragmented dune landscape to develop a multispecies conservation approach. Biol Conserv 133:490-499

Margules CR, Pressey RL (2000) Systematic conservation planning. Nature 405:243-253

Margules CR, Pressey RL, Williams PH (2002) Representing biodiversity: data and procedures for identifying priority areas for conservation. J Biosci 27:309-326

Mertens R, Wermuth H (1960) Die Amphibien und Reptilien Europas. Verlag W. Kramer, Frankfurt am Main

Millennium Ecosystem Assessment (2005) Ecosystems and human well-being: biodiversity synthesis. World Resources Institute, Washington

Monserud RA, Leemans R (1992) Comparing global vegetation maps with the Kappa statistic. Ecol Model 62:275-293

Myers N, Mittermeier RA, Mittermeier CG et al (2000) Biodiversity hotspots for conservation priorities. Nature 40:853-858

Nederlandse Vereniging voor Libellenstudie (2002) De Nederlandse libellen: Odonata. Nederlandse Fauna 4. Nationaal Natuurhistorisch Museum Naturalis, KNNV Uitgeverij and European Invertebrate Survey, Leiden

Oksanen J, Minchin PR (1997) Instability of ordination results under changes in input data order: explanations and remedies. J Veg Sci 8:447-454

Orme CDL, Davies RG, Burgess M et al (2005) Global hotspot of species richness are not congruent with endemism or threat. Nature 436:1016-1019

Overbeek GJ, Beusen AHW, Boers PCM et al (2002) Plausibiliteitsdocument STONE 2.0 Globale verkenning van de plausibiliteit van the STONE versie 2.0 voor de modellering van uit- en afspoeling van $\mathrm{N}$ en P. RIVM report 718501001. RIVM, Bilthoven

Palmer MA (1999) The application of biogeographical zonation and biodiversity assessment to the conservation of freshwater habitats in Great Britain. Aquat Conserv Mar Freshw Ecosyst 9:179-208

Pawar SS, Birand AC, Ahmed MF et al (2007) Conservation biogeography in north-east India: hierarchical analysis of cross-taxon distributional congruence. Divers Distrib 13:53-65

Pienkowski MW, Bignal EM, Galbraith CA et al (1996) A simplified classification of land-type zones to assist the integration of biodiversity objectives in land-use policies. Biol Conserv 75:11-25

Prendergast JR, Quinn RM, Lawton JH et al (1993) Rare species, the coincidence of diversity hotspots and conservation strategies. Nature 365:335-337

Reemer M, Renema W, van Steenis W et al (2009) De Nederlandse zweefvliegen (Diptera: Syrphidae). Nederlandse Fauna 8. Nationaal Natuurhistorisch Museum Naturalis, KNNV Uitgeverij \& European Invertebrate Survey, Leiden

Reid WV (1998) Biodiversity hotspots. Trends Ecol Evol 13:275-280 
Ricketts TH, Daily GC, Ehrlich PR (2002) Does butterfly diversity predict moth diversity? Testing a popular indicator taxon at local scales. Biol Conserv 103:361-370

Rodrigues ASL, Gaston KJ (2002) Optimisation in reserve selection procedures-why not? Biol Conserv 107:123-129

Schouten MA, Verweij PA, Barendregt A et al (2007) Nested assemblages of Orthoptera in the Netherlands: the importance of habitat features and life history traits. J Biogeogr 34:1938-1946

Schouten MA, Verweij PA, Barendregt A et al (2009) Determinants of species richness distribution in the Netherlands across multiple taxonomic groups. Biodivers Conserv 18:203-217

Siebel HN, During HJ (2006) Beknopte mosflora van Nederland en België. KNNV Uitgeverij, Utrecht

Sjörs H (1965) Forest regions. Acta Phytogeogr Suecica 50:48-63

Steur GGL, Heijink W (1992) Bodemkaart van Nederland, schaal 1:50.000. Stiboka, Wageningen

Tamis WLM, van 't Zelfde M, van der Meijden R et al (2005) Changes in vascular plant biodiversity in the Netherlands in the 20th century explained by their climatic and other environmental characteristics. Clim Chang 72:37-56

Tchouto MGP, Yemefack M, De Boer WF et al (2006) Biodiversity hotspots and conservation priorities in the Campo-Ma'an rain forests, Cameroon. Biodivers Conserv 15:1219-1252

Thomas JA, Telfer MG, Roy DB et al (2004) Comparative losses of British butterflies, birds, and plants and the global extinction crisis. Science 303:1879-1881

van Hinsbergen A, van Elsbroek MLP, Hendriks AM et al (2001) Knelpuntenanalyse van milieudruk in relatie tot provinciale natuurdoelen. RIVM report 4086663002. RIVM, Bilthoven

Weeda EJ (1990) Over de plantengeografie van Nederland. In: van der Meijden R (ed) Heukels' flora van Nederland. Wolters-Noordhoff, Groningen

Whitehead PJ, Bowman DJMS, Tidemann SC (1992) Biogeographic patterns, environmental correlates and conservation of avifauna in the Northern Territory, Australia. J Biogeogr 19:151-161

Whittaker RJ, Araújo MB, Jepson P, Ladle RJ, Watson JEM, Willis KJ (2005) Conservation biogeography: assessment and prospect. Divers Distrib 11:3-23

Wiens JA, Hayward GD, Holthausen RS et al (2008) Using surrogate species and groups for conservation planning and management. Bioscience 58:241-252

Williams PH, Gaston KJ (1994) Measuring more of biodiversity: can higher-taxon richness predict wholesale species richness? Biol Conserv 67:211-217

Williams P, Faith D, Manne L et al (2006) Complementarity analysis: mapping the performance of surrogates for biodiversity. Biol Conserv 128:253-264

Witte JPM, van der Meijden R (2000) Mapping ecosystems by means of ecological species groups. Ecol Eng $16: 143-152$

Zonneveld JIS (1985) Levend land. De geografie van het Nederlandse landschap. Bohn, Scheltema \& Holkema, Utrecht 